\title{
IX
}

\section{OBITER DICTA BY AGASSIZ}

TEVER try to teach what you yourself do not know, and know well. If your school board insists on your teaching anything and everything, decline firmly to do it. It is an imposition alike on pupils and teacher to teach that which he does not know. Those teachers who are strong enough should squarely refuse to do such work. This much-needed reform is already beginning in our colleges, and I hope it will continue. It is a relic of mediaeval times, this idea of professing everything. When teachers begin to decline work which they cannot do well, improvements begin to come in. If one will be a successful teacher, he must

1 The first nine of these utterances were taken down by Dr. David Starr Jordan at Penikese, in the summer of 1873, from Agassiz's talks to teachers; see Popular Science Monthly 40. 726-727, and Holder, Louis Agassiz, his Life and Works, 1893, pp. 173-176. The next five come from the article entitled ' Louis Agassiz, Teacher,' by Professor Burt G. Wilder, in The Haroard Graduate's Magazine, June, 1907, and the last three from Agassiz's posthumous article, 'Evolution and Permanence of Type,' in the Atlantic Monthly, Jan., 1874 (vol. 33). 
firmly refuse work which he cannot do successfully.

It is a false idea to suppose that everybody is competent to learn or to teach everything. Would our great artists have succeeded equally well in Greek or calculus? A smattering of everything is worth little. It is a fallacy to suppose that an encyclopaedic knowledge is desirable. The mind is made strong, not through much learning, but by the thorough possession of something.

Lay aside all conceit. Learn to read the book of nature for yourself. Those who have succeeded best have followed for years some slim thread which has once in a while broadened out and disclosed some treasure worth a lifelong search.

A man cannot be a professor of zoology on one day, and of chemistry on the next, and do good work in both. As in a concert all are musicians - one plays one instrument, and one another, but none all in perfection.

You cannot do without one specialty; you must have some base-line to measure the work [64] 
and attainments of others. For a general view of the subject, study the history of the sciences. Broad knowledge of all nature has been the possession of no naturalist except Humboldt, and general relations constituted his specialty.

Select such subjects that your pupils cannot walk without seeing them. Train your pupils to be observers, and have them provided with the specimens about which you speak. If you can find nothing better, take a house-fly or a cricket, and let each hold a specimen and examine it as you talk.

In 1847 I gave an address at Newton, Massachusetts, before a Teachers' Institute conducted by Horace Mann. My subject was grasshoppers. I passed around a large jar of these insects, and made every teacher take one and hold it while $I$ was speaking. If any one dropped the insect, I stopped till he picked it up. This was at that time a great innovation, and excited much laughter and derision. There can be no true progress in the teaching of natural science until such methods become general. 
There is no part of the country where, in the summer, you cannot get a sufficient supply of the best specimens. Teach your children to bring them in themselves. Take your text from the brooks, not from the book-sellers. It is better to have a few forms well known than to teach a little about many hundred species. Better a dozen specimens thoroughly studied as the result of the first year's work, than to have two thousand dollars' worth of shells and corals bought from a curiosity-shop. The dozen animals would be your own.

The study of nature is an intercourse with the highest mind. You should never trifle with nature. At the lowest her works are the works of the highest powers-the highest something, in whatever way we may look at it.

It is much more important for a naturalist to understand the structure of a few animals than to command the whole field of scientific nomenclature.

Methods may determine the result.

The only true scientific system must be one [66] 
in which the thought, the intellectual structure, rises out of, and is based upon, facts.

He is lost, as an observer, who believes that he can, with impunity, affirm that for which he can adduce no evidence.

Have the courage to say: 'I do not know.'

Since the ability of combining facts is a much rarer gift than that of discerning them, many students lost sight of the unity of structural design in the multiplicity of structural detail. ${ }^{1}$

It cannot be too soon understood that science is one, and that whether we investigate language, philosophy, theology, history, or physics, we are dealing with the same problem, culminating in the knowledge of ourselves. Speech is known only in connection with the organs of man, thought in connection with his brain, religion as the expression of his aspirations, history as the record of his deeds, and physical sciences as the laws under which he lives. ${ }^{2}$

The most advanced Darwinians seem reluctant to acknowledge the intervention of an

1 Atlantic Monthly 33. 93.

'Atlantic Monthly 33. 95. 
intellectual power in the diversity which obtains in nature, under the plea that such an admission implies distinct creative acts for every species. What of it, if it were true? Have those who object to repeated acts of creation ever considered that no progress can be made in knowledge without repeated acts of thinking? And what are thoughts but specific acts of the mind? Why should it then be unscientific to infer that the facts of nature are the result of a similar process, since there is no evidence of any other cause? The world has arisen in some way or other. How it originated is the great question, and Darwin's theory, like all other attempts to explain the origin of life, is thus far merely conjectural. I believe he has not even made the best conjecture possible in the present state of our knowledge.

The more I look at the great complex of the animal world, the more sure do I feel that we have not yet reached its hidden meaning, and the more do I regret that the young and ardent spirits of our day give themselves to speculation rather than to close and accurate investigation. ${ }^{3}$

'Atlantic Monthly 33. 101.

[68] 